\title{
Use of biofilter as pre-treatment of polluted river water for drinking water supply
}

\author{
Suprihatin Suprihatin, Bunga Cahyaputri, Muhammad Romli, Mohamad Yani ${ }^{\dagger}$ \\ Division of Environmental Engineering and Management, Department of Agroindustrial Technology, Faculty of Agricultural Engineering and \\ Technology, Bogor Agricultural University IPB Dramaga Campus, PO Box 220, Bogor, West Java, Indonesia
}

\begin{abstract}
Innovations in the biofiltration process can provide effective solutions to overcome crucial water pollution problems. The elimination of pollutants is a result of the combined effects of biological oxidation, adsorption and filtration processes. This research aims to evaluate the performance of quartz sand biofiltration for removing total suspended solids, turbidity, color, organic matter, and ammonium from polluted river water and develop an empirical model for designing quartz sand biofilters for the treatment of polluted river water. Experiments were conducted using two biofilter units filled with quartz sand as filter media. A set of experiments were performed to evaluate the effect of hydraulic retention time on biofilter performance in removing water contaminants. The kinetics of organic matter removal were also determined to describe the performance of the biofilter. The results show that biofiltration can significantly remove river water pollutants. Removal efficiency depends on the applied hydraulic retention time. At a hydraulic retention time of two hours, removal efficiencies of total organics, ammonium and total suspended solids were up to $78 \%, 82 \%$, and $91 \%$, respectively. A model for designing quartz sand biofiltration has been developed from the experimental data.
\end{abstract}

Keywords: Biofiltration, Organics removal, Pollutted river water, Pre-treatment, Raw water

\section{Introduction}

The quality standard of raw water in many regions of Indonesia has been diminished due to industrial, commercial, residential and farming activities. This leads to increased water treatment costs, as well as public health risks. Various attempts to control river water pollution have not been entirely successful; even more, the situation has worsened in some densely populated areas. Unofficial reports state that more than $60 \%$ of the monitored rivers are polluted. In accordance to the Indonesian Government Regulation No. 82/2001, the river quality monitoring program has also observed a tendency towards an increasing number of rivers in the heavily polluted category [1]. Many polluted rivers are the source of raw water for drinking water supplies, regardless of their water quality. This will result in increased water treatment costs and risks to public health.

Innovations in biofiltration technology can provide effective solutions to overcome these crucial problems. In biofiltration, pollutant elimination is affected by a combination of biological

This is an Open Access article distributed under the terms of the Creative Commons Attribution Non-Commercial License (http://creativecommons.org/licenses/by-nc/3.0/) which permits unrestricted non-commercial use, distribution, and reproduction in any medium, provided the original work is properly cited.

Copyright (c) 2017 Korean Society of Environmental Engineers oxidation, adsorption and filtration processes. The biofiltration process uses solid materials as a matrix, wherein microorganisms involved in the biological degradation of pollutants grow. The matrix can be gravel, sand, plastic, and activated carbon particles. Depending on the nutrient supply, microorganisms will grow and continuously evolve, coating the surface of the media and forming a thin layer of biomass called biofilm.

The biofiltration process has been reported as a cost effective method for the elimination of a variety of organic and inorganic pollutants, even for substances classified as relatively harmful, toxic, and hardly biodegradable compounds. The characteristics of the solid material used for filter media plays an important role in achieving the desired efficiency level of pollutants removal. The effectiveness of the filter media is influenced by the type of material, shape, size, surface area, the porosity, and the surface roughness [2]. One potential biofilter media for water treatment is quartz sand because of its abundant availability. Quartz sand grains have stable properties and are relatively small in size, so that the contact surface area covered with biofilm is relatively broad, and the cavity between the particles is relatively small.

Received September 9, 2016 Accepted January 16, 2017

${ }^{\dagger}$ Corresponding author

Email: f226yani@gmail.com

Tel: +62-251-862-1974 Fax: +62-251-862-1974 
Thus, the contact between raw water pollutants and the biofilm will be greater. This condition is preferable for improving pollutant removal efficiency via the biofiltration process [3].

The biofilter process has been shown to be effective for various purposes of water and waste water treatment, such as the advanced treatment of wastewater $[4,5]$, the elimination of pesticides [6], and the elimination of toxic compounds [7-9]. These studies were mostly directed at eliminating high concentrations of pollutants from wastewater and partly directed at advanced wastewater treatments to eliminate nutrients (nitrification, denitrification and phosphor elimination). Using the biofiltration process specifically for pre-treating polluted river water as raw water for the drinking water supply, which contains a relatively low concentration of pollutants, has not been extensively developed, despite the demand as mentioned above.

The treatment of raw water with biofilters can improve the quality of raw water, and thus the quality of produced drinking water, reducing the risks to public health. By implementing a well-designed biofiltration system for the pre-treatment of raw water, the capacity of existing water treatment plants can be increased without significant disruptions to the design and operation of the existing water treatment systems. The most important factor in the biofiltration operation is the hydraulic retention time of the biofiltration system. The applied hydraulic retention time represents the amount and supply of food for microorganisms in biofilms (also called the pollutant load) and the duration of contact time between the pollutants and microorganisms. The optimum retention time is important, especially for the technical purpose of determining the size of the biofilter needed for treatment at a certain raw water flow rate and for a certain quality level of treated raw water.

This research aimed to i) evaluate the performance of a quartz sand biofilter process for the removal of physical pollutants, organic matter, and ammonium from polluted river water and ii) develop an empirical model for designing a quartz sand biofilter for pre-treating polluted river water as raw water for the drinking water supply.

\section{Experimental Procedures}

The raw water used in the experiments was taken from the Cihideung River, at the same spot as the inlet of the water treatment plant of the Bogor Agricultural University Campus, Bogor, Indonesia. The experimental equipment consisted of a raw water tank and two units of biofilter that operated in parallel as replications. The schematic diagram of the biofiltration system can be seen in Fig. 1. The biofilter unit was made of a plastic drum with a $49 \mathrm{~cm}$ diameter and a $56 \mathrm{~cm}$ height (working volume of $135 \mathrm{~L}$ ), filled with quartz sand as filter media and equipped with an air supply and regulator taps. The volume of quartz sand media was approximately $2 / 3$ of the working volume of the biofilter (96 L). The biofiltration systems were operated in upflow mode.

\subsection{Characterization of Raw Water}

The characterization of river water was conducted by determining the physical and chemical parameters, such as total suspended solids (TSS), turbidity, color, $\mathrm{pH}$, chemical oxygen demand (COD),

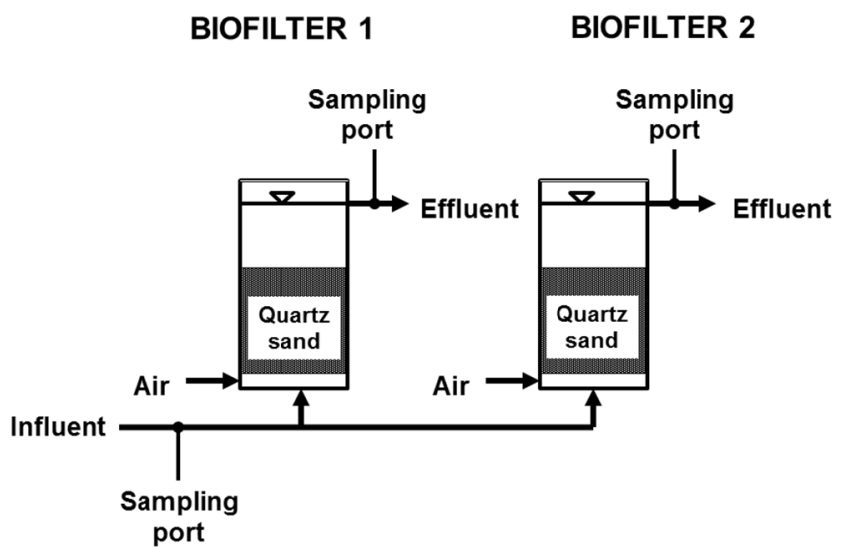

Fig. 1. Schematic diagram of biofiltration system used in the experiments.

Table 1. Physical Properties of the River Water during Dry and Rainy Seasons

\begin{tabular}{cccc}
\hline Parameter & Unit & Rainy condition & No rain condition \\
\hline TSS & mg/L & 159 & 69 \\
Turbidity & FTU & 170 & 60 \\
Color & PtCo & 1200 & 330 \\
pH & - & 6.5 & 6.8 \\
\hline
\end{tabular}

and ammonium. COD is used as a representation of organic matter. The laboratory analysis was carried out according to the standard methods of APHA [10]. Table 1 shows the water characteristics during the rainy and dry seasons (no rain condition). During the rainy season, the physical properties of TSS, turbidity, and color of the river water were much higher than those in the dry season.

\subsection{Acclimatization Process}

The acclimatization of microorganisms was done by continuous feeding of raw water through the biofilter system for four weeks at $27-29^{\circ} \mathrm{C}$ and with a sufficient rate of aeration to allow biofilm formation on the filter media surface. The acclimatization process was intended to achieve a steady state growth of microorganisms. The removal efficiency of the physical and organic substance parameters were used as an indication of the acclimated conditions and the stable removal rate.

\subsection{Effect of Hydraulic Retention Time}

After reaching acclimated conditions, the experiment was conducted to evaluate the effect of hydraulic retention time on pollutants removal efficiency. Four levels of hydraulic retention time (t), namely, $3 \mathrm{~h}, 2 \mathrm{~h}, 1 \mathrm{~h}$ and $0.5 \mathrm{~h}$ were evaluated, and each level was run for five days. The applied retention time was expressed as an "empty bed retention time".

The performance of the biofilter was measured by physical parameters (TSS, turbidity, and color), COD, ammonium raw water (influent) and treated water (effluent). Samples were taken and tested every day for each level of hydraulic retention time. Water quality parameters were analyzed in the laboratory using the 
standard procedures of APHA (2005) [10], whereas dissolved oxygen and temperature were measured directly in the biofilter.

\subsection{Kinetics of Organic Removal Processes}

The removal of organic matter in biofilters was evaluated by adopting the first order reaction model, referring to Shareefdeen et al. [11]. The model is used to express the relationship between the concentration of residual organic material in the effluent as a function of the concentration of organic matter in the influent, hydraulic residence time, and a first-order reaction constant.

Operating at steady state and assuming a first order reaction, the model equations to describe the elimination of organic matter (COD) as a limiting substrate is expressed as follows:

$$
\begin{gathered}
-r=k \cdot C_{\text {out }} \\
d F / d V=-r \\
k_{1}=(Q / V) \cdot \ln \left(C_{\text {in }} / C_{\text {out }}\right)
\end{gathered}
$$

With hydraulic residence time $t$, where $t=V / Q$, the equation can be rearranged as follows:

$$
C_{\text {out }}=C_{\text {in }} \cdot e^{-k_{1} \cdot t}
$$

Eq. (4) can be rearranged as follows:

$$
\frac{C_{\text {out }}}{C_{\text {in }}}=e^{-k_{1} \cdot t}
$$

The COD removal efficiency can then be written as follows:

$$
\eta=1-\frac{C_{o u t}}{C_{\text {in }}}=1-e^{-k_{1} \cdot t}
$$

Further, Eq. (5) can be expressed as follows:

$$
-\ln \left[\frac{C_{\text {out }}}{C_{\text {in }}}\right]=k_{1} \cdot t
$$

where $C_{\text {out }} / C_{\text {in }}$ is the ratio of the concentration of COD in the effluent to the concentration of residual COD in the influent.

The reaction rate constant can be determined from the experimental data with the help of Eq. (5) by plotting $t$ vs $-\ln \left(C_{\text {out }} / C_{\text {in }}\right)$. From the presentation of experimental data in graph form, the relationship can be obtained by a straight line with a slope that represents the value of the constant $\left(k_{1}\right)$. By knowing the value of $\mathrm{k}_{1}$, the need for a residence time $t$ and the required biofilter reactor volume can be determined using Eq. (8) and Eq. (9) as follows:

$$
\begin{array}{r}
t=\frac{-\ln \left(\frac{C_{\text {out }}}{C_{\text {in }}}\right)}{k_{1}} \\
V=\frac{-\ln \left(\frac{C_{\text {out }}}{C_{\text {in }}}\right) \cdot Q}{k_{1}}
\end{array}
$$

\section{Results and Discussion}

\subsection{Pollutants Removal}

Various types of pollutants can be eliminated by using the biofiltration system. In addition to the filtration effects of the quartz sand matrix, bacteria in the biofilter (biofilm) also oxidized the organic materials into simpler compounds, such as water and carbon dioxide [12].

The start-up of biofiltration to allow biofilm development was carried out with a relatively high hydraulic retention time and excessive dissolved oxygen at 5-6 mg/L. The retention time was maintained at $8 \mathrm{~h}$ (day 0-22) and was reduced to $6 \mathrm{~h}$ (day 23-27). Fig. 2 shows the COD removal efficiency during the start-up. The relatively low flow rate enabled the raw water to have a long contact time with the media and an adequate supply of oxygen, and thus speeding up the formation of biofilm on the media. During the first $3 \mathrm{~d}$ of operation, the COD elimination rate was relatively low at approximately $30 \%$. After $7 \mathrm{~d}$, the removal efficiency of organic matter increased to $80-90 \%$. The bacterial layers were visually observed on the media, indicating biofilm formation and development. After $18 \mathrm{~d}$ of operation, the organic removal efficiency was relatively stable at approximately $90 \%$; at this point, a steady-steady condition had been achieved.

Experiments were then conducted to study the biofilter response against the changes of the organic load through reducing the contact time (hydraulic retention time). The hydraulic retention time was reduced to $3 \mathrm{~h}$ and was followed by a step-by-step reduction down to $0.5 \mathrm{~h}$ by adjusting the raw water flow rate. Each treatment was run for $5 \mathrm{~d}$, assuming that pseudo steady-state had been achieved. The following paragraphs discuss biofiltration performance during the experiments.

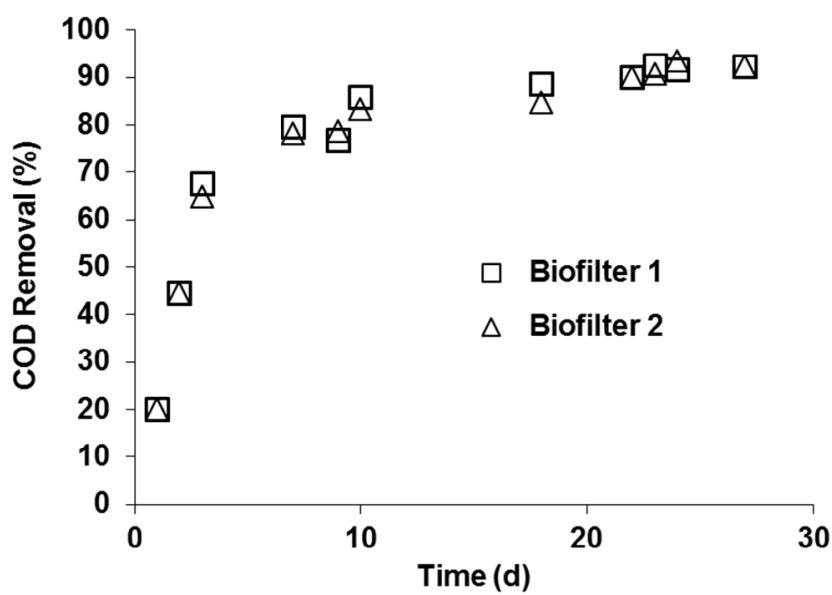

Fig. 2. COD removal during acclimation process.

\subsubsection{TSS, turbidity, and color}

TSS, turbidity and color are the most important physical parameters of raw water quality. The suspended solids content can be significantly reduced by the biofilter. Within the range of the hydraulic residence time from $0.5 \mathrm{~h}$ to $3 \mathrm{~h}$, TSS elimination rates ranged from 46.5 to $92.6 \%$ (Fig. 3). The TSS contents of the effluent 


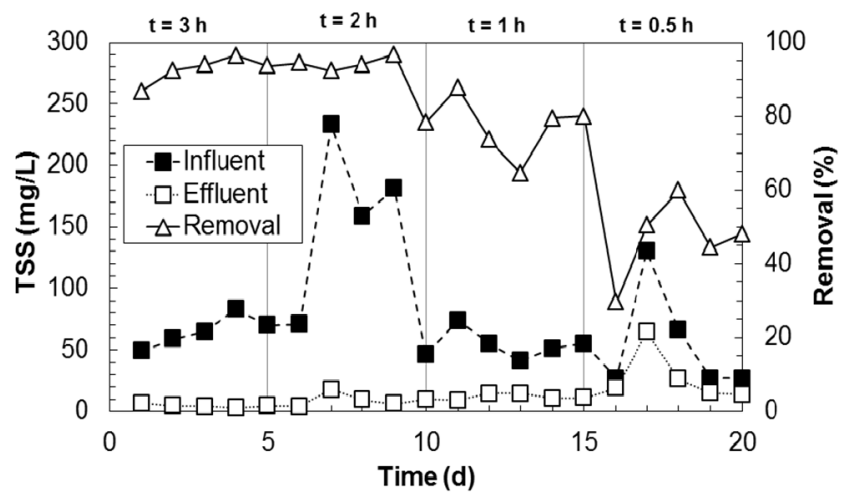

Fig. 3. Effect of hydraulic residence time on TSS.

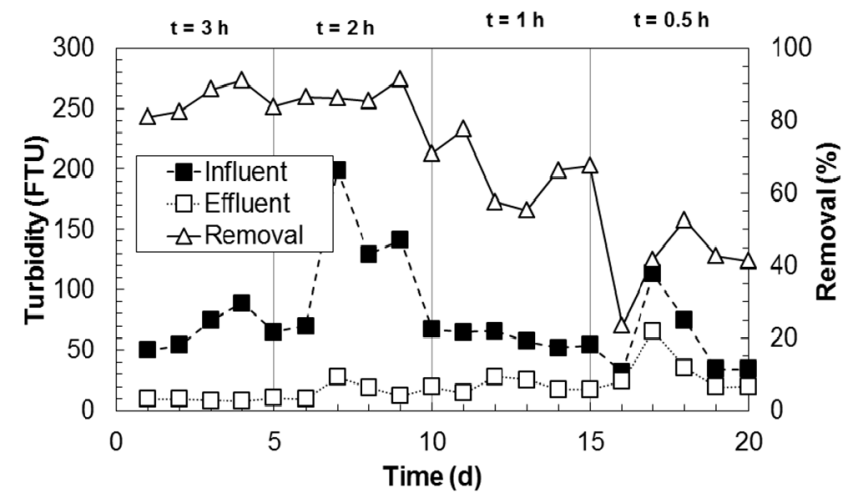

Fig. 4. Effect of hydraulic residence time on turbidity.

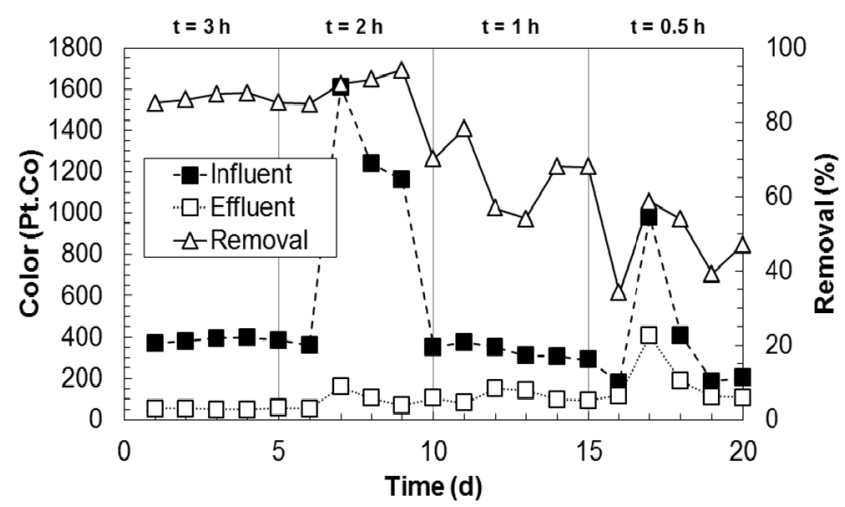

Fig. 5. Effect of hydraulic residence time on color.

varied from $4.5 \mathrm{mg} / \mathrm{L}$ to $25.2 \mathrm{mg} / \mathrm{L}$, depending on the applied hydraulic retention time and the TSS content of the influent. A lower TSS in water will lead to reduced coagulant consumption in the subsequent treatment of raw water.

The water turbidity also decreased in line with the decrease in TSS. The turbidity removal efficiency was in the range of $40.3 \%$ and $85.4 \%$ (Fig. 4), with effluent turbidity at 9.2 FTU to 33.1 FTU. A significant decrease in the water color was also observed. The rates of color removal at hydraulic residence times of $1 / 2$, 1, 2 and $3 \mathrm{~h}$ were $46.6 \%, 65.1 \%, 86.1 \%$, and $86.4 \%$, respectively (Fig. 5). The removal of the physical pollutants, particularly TSS and turbidity, was most likely due to the effects of the physical filtration of the quartz sand. It was also possible that organic particles caught by the quartz sand particles were degraded biologically by the biofilm. The color reduction was most likely related to the decrease in dissolved organic materials by microorganism activity in the biofilms.

\subsubsection{Organic matter}

The organic matter in water is expressed in terms of COD. The organic matter in raw water can increase the use of chemicals (coagulant/flocculants) during water treatment [13]. Moreover, the organic materials may trigger the formation of by-products, such as trihalomethane $\left(\mathrm{CHCl}_{3}\right)$ compounds, in the water treatment plants that are applying chlorination for disinfection purposes. These by-products are considered carcinogenic compounds [14]. The dissolved organic matter can be degraded microbiologically in biofiltration systems. The heterotroph bacteria play an important role in the decomposition of the organics. Widayat et al. [15] identified Bacillus subtilis, Clostridium, and Proteus sp. as the most dominant decomposers of organic compounds in the biofiltration system.

The biofiltration system reduced the organic matter content from $385 \mathrm{mg} / \mathrm{L}$ to $18-76 \mathrm{mg} / \mathrm{L}$, depending on the applied hydraulic residence time. In general, the longer the hydraulic residence time, the lower the residual organic matter in the treated water. Fig. 6 shows the COD influent and effluent, as well as the COD removal at various hydraulic residence times. The average removal rates of organic matter at the hydraulic retention times of 3,2, 1, and $0.5 \mathrm{~h}$ were $88.2 \%, 77.7 \%, 57.7 \%$, and $40.3 \%$, respectively, and had average COD values in the treated water of $18.22 \mathrm{mg} / \mathrm{L}, 25.16$ $\mathrm{mg} / \mathrm{L}, 41.31 \mathrm{mg} / \mathrm{L}$, and $75.88 \mathrm{mg} / \mathrm{L}$, respectively. From these figures, the pre-treatment of raw water using a biofilter at a hydraulic retention time of either $3 \mathrm{~h}$ or $2 \mathrm{~h}$ can meet the quality standards according to the Indonesian Government Regulation No. 82 of 2001 [1].

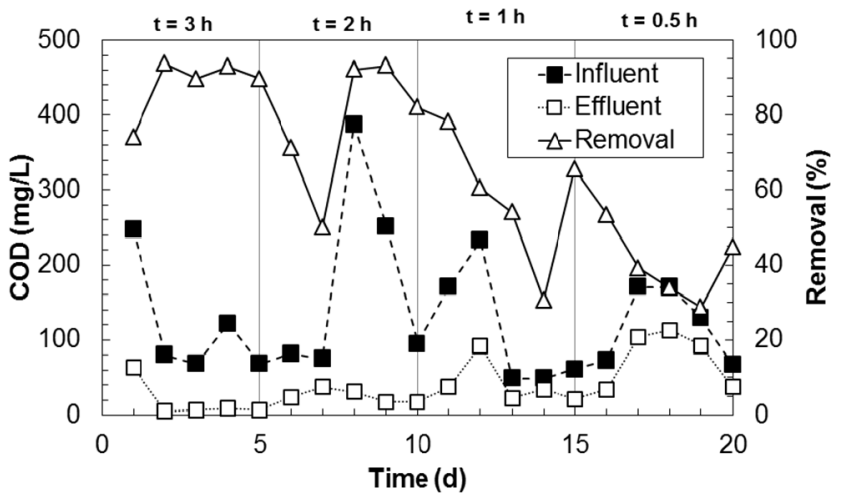

Fig. 6. Effect of hydraulic residence time on COD.

\subsubsection{Ammonium}

Ammonium cannot be eliminated in conventional drinking water treatment systems using the chemical-physical treatment (coagulation/flocculation and sedimentation). On the other hand, it can be oxidized biologically in the biofilter system through the nitrification process. Fig. 7 shows the ammonium concentration in the influent and effluent, as well as its removal rates at various 
Table 2. Values of Inlet and Outlet COD at Various Hydraulic Retention Times

\begin{tabular}{|c|c|c|c|c|c|c|}
\hline \multirow{2}{*}{$\begin{array}{l}\text { time } \\
\text { (h) }\end{array}$} & \multicolumn{2}{|c|}{$\mathrm{COD}_{\text {in }}$} & \multicolumn{2}{|c|}{$\mathrm{COD}_{\text {out }}$} & \multicolumn{2}{|c|}{ COD Removal (\%) } \\
\hline & Biofilter 1 & Biofilter 2 & Biofilter 1 & Biofilter 2 & Biofilter 1 & Biofilter 2 \\
\hline 0.5 & 122.2 & 122.2 & 77.2 & 74.8 & 36.8 & 38.8 \\
\hline 1 & 112.6 & 112.6 & 42.8 & 39.8 & 62.0 & 64.7 \\
\hline 2 & 178.4 & 178.4 & 24.2 & 26.0 & 86.4 & 85.4 \\
\hline 3 & 117.2 & 117.2 & 18.2 & 18.4 & 84.5 & 84.3 \\
\hline
\end{tabular}

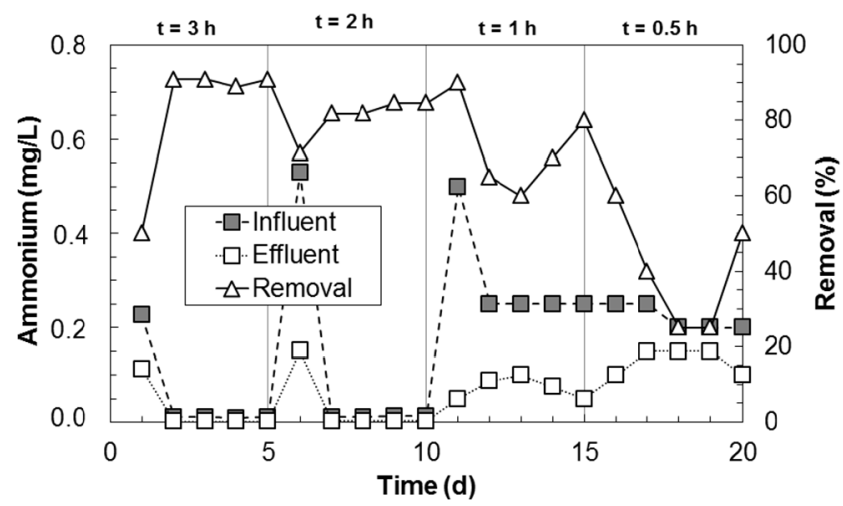

Fig. 7. Effect of hydraulic residence time on ammonium.

hydraulic retention times. The biofiltration system can reduce the ammonium concentration from $0.05-0.22 \mathrm{mg} / \mathrm{L}$ to $0.02-0.13$ $\mathrm{mg} / \mathrm{L}$. Depending on the applied hydraulic residence time, the ammonium removal rates within the range of the hydraulic residence times were in the range of $40.0 \%-82.8 \%$. The ammonium removal increased with increasing hydraulic retention time.

Grady and Lim [16] reported that microorganisms involved in nitrification are categorized as autotrophic bacteria. Nitrification is the process of converting ammonium to nitrite $\left(\mathrm{NO}_{2}^{-}\right)$. The formed nitrite is then converted into nitrate $\left(\mathrm{NO}_{3}{ }^{-}\right)$. The conversion of ammonium to nitrite $\left(\mathrm{NO}_{2}^{-}\right)$is done by bacteria Nitrosomonas, and the conversion of nitrite to nitrate is done by bacteria Nitrobacter. Both types of bacteria are aerobic bacteria, so the nitrification process requires dissolved oxygen in a sufficient amount to support the metabolic processes.

Technically, ammonium in the water causes a decrease in the effectiveness of disinfection with chlorine (increasing the need of chlorine). In principle, levels of ammonium $\left(\mathrm{NH}_{4}^{+}\right)$in the raw water cannot be eliminated in conventional water treatment systems, so ammonium will remain in the treated water. Ammonium reacts with chlorine $\left(\mathrm{Cl}_{2}\right)$ added in the disinfection process in accordance with the following equation:

$$
\mathrm{NH}_{4}^{+}+\mathrm{Cl}_{2}+2 \mathrm{HOCl} \rightarrow \mathrm{NCl}_{3}+2 \mathrm{H}^{+}+\mathrm{Cl}^{-}+2 \mathrm{H}_{2} \mathrm{O}
$$

The low level of ammonium from introducing the biofiltration pre-treatment also means reducing the need for chlorine in the disinfection process. According to the reaction, one mole (18 g) of ammonium requires one mole of chlorine (71 g). As an illustration, an ammonium removal of $1.5 \mathrm{mg} / \mathrm{L}$ to $0.5 \mathrm{mg} / \mathrm{L}$ will decrease the chlorine need from $6.3 \mathrm{mg} / \mathrm{L}$ to $2.1 \mathrm{mg} / \mathrm{L}$ (stoichiometric calculation).

\subsection{Kinetics of Organic Substances Removal}

To determine the kinetics and the best theoretical model that fits the experimental data, COD values at the steady state condition were averaged for each of the four hydraulic retention times evaluated (Table 2). The average COD concentrations $\left(C_{i n}\right.$ and $C_{\text {out }}$ ) and $\mathrm{t}$ data were used to find the kinetics of COD removal in the biofilter.

The presentation of the experimental data of $-\ln \left(C_{\text {out }} / C_{\text {in }}\right)$ vs. $t$ according to Eq. (6) in the form of a graph results in a linear relationship as shown in Fig. 8. From the correlation coefficients, it is clear that the data of the biofilter filled with quartz sand follows a first order kinetics. From the graph, a linear equation with a slope of $0.71 \mathrm{~h}^{-1}$, i.e., a first-order reaction constant, was determined. Thus, Eq. (4) can be written as follows:

$$
\begin{gathered}
C_{\text {out }}=C_{\text {in }} \cdot e^{-0.71 \cdot t}, \text { or } \\
C_{\text {out }}=C_{\text {in }} \cdot e^{-0.71 \cdot \mathrm{V} / Q}
\end{gathered}
$$

It should be noted here that the value of $\mathrm{k}$ is an aggregate constant value that is determined by various factors such as the specific growth, density of the biofilm, the surface area per unit volume of the biofilter, biofilm thickness, and the coefficient yield that is equivalent to the amount of biomass produced per unit of substrate consumed.

The removal efficiency of organic matter that was determined from Eq. (11) was compared with that of the organic materials calculated from the experimental data, as shown in Fig. 9. It can be seen that the values of organic matter removal efficiency

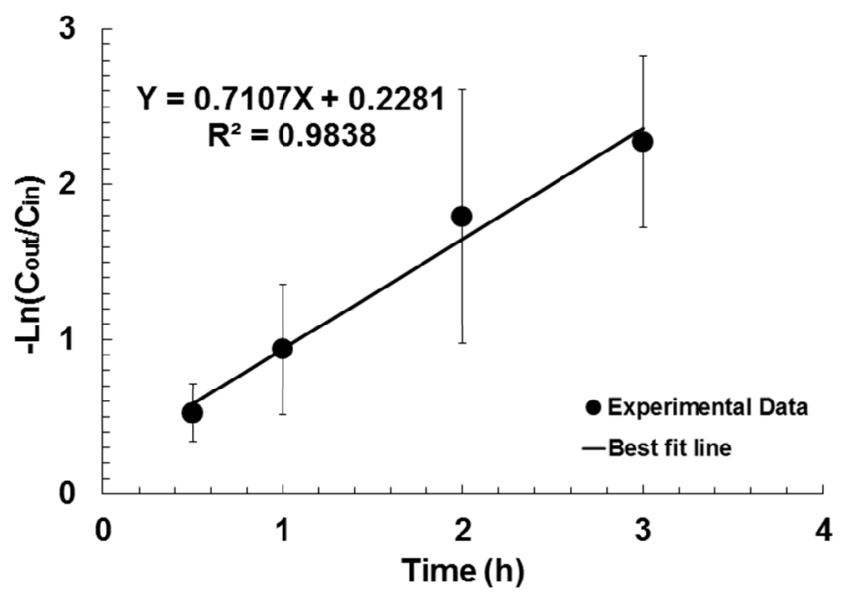

Fig. 8. Data presentation according to first order kinetics. 


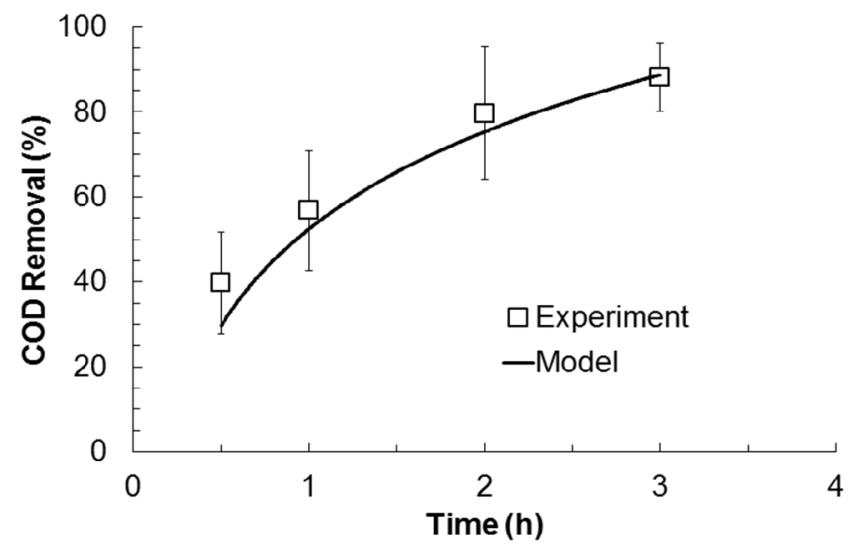

Fig. 9. Comparison of the model with experimental data.

predicted by the model corresponds well with the experimental data. The model can be used to obtain information on the behavior of the removal rate of organic materials in a given value of $t$ or $V$ and $Q$. The required biofilter volume can be predicted for practical purposes. As an illustration, to reduce a COD value $\left(C_{\text {in }}\right)$ from $100 \mathrm{mg} / \mathrm{L}$ to $20 \mathrm{mg} / \mathrm{L}$, the applied hydraulic residence time $(t=$ $V / Q$ ) should be $2.8 \mathrm{~h}$. In the same way, for the treatment of raw water with a volumetric flow $(Q)$ of $50 \mathrm{~L} / \mathrm{s}$, it is necessary to install a $500 \mathrm{~m}^{3}$ biofilter.

The $k_{1}$ value is influenced by the characteristics of the media, so it is necessary that $k_{1}$ is determined experimentally for each media type and operating condition. As indicated by Eq. (9), the required biofilter volume is largely determined by the initial organic substance concentration $\left(C_{i n}\right)$ and the targeted concentration of residual organic matter in the processed water $\left(C_{\text {out }}\right)$. A lower concentration of residual organic substances and a higher concentration of organic matter in the raw water will require the greater volume of biofilter.

\section{Conclusions and Recommendation}

\subsection{Conclusions}

An application of a quartz sand biofilter can significantly improve the quality of raw water, as shown by the decreased values of TSS, turbidity, color, organic matter, and ammonium. Hydraulic retention time affects pollutant removal efficiency and treated water quality. At 2 hours hydraulic retention time, removal efficiencies of $77.7 \%, 81.9 \%, 91.1 \%, 84.1 \%$, and $86.1 \%$ were obtained for organics, ammonium, TSS, turbidity, and color, respectively. This operating condition has resulted in water quality that meets the requirements of the Indonesian Government Regulation No. 82 of 2001 in terms of TSS, turbidity, color, organic matter content, and ammonium. The decrease in TSS and turbidity will result in the decrease of coagulant consumption in the subsequent treatment of raw water, whereas the decrease in ammonium will lower the need of chlorine as a disinfectant. Both may lead to a decreased cost of the overall water treatment.

The removal of organic matter (expressed in COD) from the river water can be described by a first-order reaction kinetics model.
From the experimental data, the kinetic constant was determined as $0.71 \mathrm{~h}^{-1}$, so the relationship between the concentration of residual organic material $\left(C_{\text {out }}\right)$, the influent concentration of organic matter $\left(C_{i n}\right)$, and hydraulic residence time $(\mathrm{t})$ can be expressed quantitatively as follows: $C_{\text {out }}=C_{\text {in }} \cdot \exp (-0.71 . \mathrm{t})$. The model can be used as a tool to describe the behavior of organic matter elimination in the biofiltration system and for determining the biofiltration volume needed for treatment of a certain raw water flow rate at a certain quality level of the treated raw water.

\subsection{Recommendation}

Further research and development of the biofilter process for the treatment of polluted river water as raw water for the drinking water supply is still required to optimize these advantages, including testing the stability of the system against shock load, process optimization, and a comprehensive techno-economic analysis.

\section{Nomenclature}

COD Chemical oxygen demand (mg/L)

$\mathrm{C}_{\text {in }} \quad \mathrm{COD}$ concentration in the influent $\left(\mathrm{kg} / \mathrm{m}^{3}\right)$

$\mathrm{C}_{\text {out }} \quad \mathrm{COD}$ concentration in the effluent $\left(\mathrm{kg} / \mathrm{m}^{3}\right)$

$\mathrm{F} \quad$ COD mass flow rate $(\mathrm{kg} / \mathrm{h})$

$\mathrm{k}_{1} \quad$ First order reaction rate constant $\left(\mathrm{h}^{-1}\right)$

Q Volumetric flow rate $\left(\mathrm{m}^{3} / \mathrm{h}\right)$

r Degradation rate of organic matter $\left(\mathrm{kg} / \mathrm{m}^{3} . \mathrm{h}\right)$

$\mathrm{t} \quad$ Hydraulic retention time (h)

TSS Total suspended solids (mg/L)

V Volume $\left(\mathrm{m}^{3}\right)$

\section{References}

1. Indonesian Government Regulation No. 82 Year 2001 on Water Quality Management and Control of Environmental Pollution. Jakarta. c2016 [cited 21 Mei 2016]. Available from: http://jdih.menlh.go.id/pdf/ind/IND-PUU-3-2001-lLampiran.p df.

2. Ramirez-Lopez EM, Corona-Hernandez J, Avelar-Gonzalez FJ, Omil F, Thalasso F. Biofiltration of methanol in an organic biofilter using peanut shells as medium. Bioresource Technol. 2010;101:87-91.

3. Baig SA, Mahmood Q, Nawab B, Shafqat MN, Pervez A. Improvement of drinking water quality by using plant biomass through household biosand filter-A decentralized approach. Ecol. Eng. 2011;37:1842-1848.

4. Pleha SV. Biofiltration as second biological stage (in German). Korrespondenz Abwasser 1987;3:230-234.

5. Jou CJ, Huang GC. A pilot study for oil refinery wastewater treatment using a fixed film bioreactor. $A d v$. Environ. Res. 2003;7:463-469.

6. Timmer G, Albrecht JJ, Richter H. The biofiltration as method for wastewater treatment and pesticides removal (in German). Korrespondenz Abwasser 1993;5:764-780. 
7. Eker S, Kargi F. COD, para-chlorophenol and toxicity removal from synthetic wastewater using rotating tubes biofilm reactor (RTBR). Bioresource Technol. 2010;101:9020-9024.

8. Sheth N, Dave S. Enhanced biodegradation of Reactive Violet 5R manufacturing wastewater using down flow fixed film bioreactor. Bioresource Technol. 2010;101:8627-8631.

9. Li HQ, Han HJ, Du MA, Wang W. Removal of phenols, thiocyanate and ammonium from coal gasification wastewater using moving bed biofilm reactor. Bioresource Technol. 2011;102:4667-4673.

10. APHA [American Public Health Association]. Standard methods for the examination of water and wastewater. 22nd ed. In: Rice EW, Baird RB, Eaton AD, Clesceri LS, eds. Washington D.C.: APHA, AWWA, WEF; 2012. p. 2.5-5.18.

11. Shareefdeen ZM, Ahmed W, Aidan A. Kinetics and modeling of $\mathrm{H}_{2} \mathrm{~S}$ removal in a novel biofilter. Adv. Chem. Eng. Sci. 2011;1:72-76.

12. Neori A, Chopin T, Troell M, et al. Integrated aquaculture:
Rationale, evolution, and state of the art emphasizing seaweed biofiltration in modern mariculture. Aquaculture 2004;231: 361-391.

13. Matilainen A, Sillanpää M. Removal of natural organic matter from drinking water by advanced oxidation processes (Review paper). Chemosphere 2010;80:351-365.

14. Hsu CH, Jeng WL, Chang RM, Chien L, Han BC. Estimation of potential lifetime cancer risks for trihalomethanes from consuming chlorinated drinking water in Taiwan. Environ. Res. 2011;85:77-82.

15. Widayat W, Suprihatin S, Herlambang A. Removal of ammonia for the raw water quality improvement of water treatment plant Bojong Renged by using biofiltration with plastic media of hornet nest type (in Bahasa Indonesia). J. Air Indonesia 2010;6:64-75.

16. Grady CPL, Lim HC. Biological wastewater treatment: Theory and applications. New York: Marcel Dekker Inc; 1980. p. 787-831. 